\title{
Effects of bile acids and endotoxin on the function and morphology of cultured hamster Kupffer cells
}

\author{
Satoshi Takiguchi and Akitoshi Koga \\ Department of Surgery I, Kyushu University Faculty of Medicine, Higashiku Maedashi 3-1-1, Fukuoka 812, Japan
}

Summary. The mechanisms of hepatic reticuloendothelial cell dysfunction in obstructive jaundice were investigated using cultured hamster Kupffer cells. The introduction of free bile acids, cholic acid (CA) at concentrations over $2 \mathrm{mM}$ and chenodeoxycholic acid (CDCA) over $1 \mathrm{mM}$ inhibited colloidal carbon pinocytosis. CA and CDCA at concentrations over $0.5 \mathrm{mM}$ inhibited IgG-coated sheep red blood cell phagocytosis. With the application of conjugated bile acid and endotoxin at concentrations over $50 \mu \mathrm{g} / \mathrm{ml}$, endocytic function was inhibited. With bile acids, a dose-dependent increase in the concentration of $\beta$-glucuronidase occurred in the culture medium, and with endotoxin a timedependent increase in $\beta$-glucuronidase was noted. Bile acids produced alterations in cell organelles before destruction of the cell membrane. The presence of endotoxin led to the appearance of large vacuoles in the cytoplasm. These observations suggest that bile acids and endotoxin inhibit Kupfer cells by different mechanisms. We tentatively conclude that bile acids rather than endotoxin influence Kupffer cells in vivo.

Key words: Kupffer cell - Bile acid - Endotoxin - Bile duct obstruction

\section{Introduction}

Preoperative biliary drainage in patients with severe obstructive jaundice may help to minimise complications such as sepsis, endotoxemia, disseminated intravascular coagulation (DIC) (Wardle and Wright 1970; Oka et al. 1983), acute respiratory distress syndrome (ARDS), renal failure (Bailey 1976; Wilkinson et al. 1976), hepatic failure (Wilkinson et al. 1974), and multiple organ failure (MOF) (Keller et al. 1985). In obstructive jaundice,

Offprint requests to: A. Koga at the above address the deposition of bile in tissues occurs, the entry of bacteria and endotoxin from the intestine increases, and functions of the hepatic reticuloendothelial system are disturbed (Wilkinson et al. 1976; Bailey 1976).

The exact mechanism involved in dysfunction of the hepatic reticuloendothelial system in patients with obstructive jaundice remains obscure. In the present study, we attempted to determine how the concentration of bile acids (Adler et al. 1977; Eklund et al. 1980) and endotoxin (Wilkinson et al. 1976; Bailey 1976), which increase in the sinusoids in obstructive jaundice, affect the function and morphology of the cultured hamster Kupffer cells (KCs).

\section{Materials and methods}

Animals. Adult female Golden hamsters (Seiwa Co., Nakatsu, Oita, Japan), weighing 100-150 g, were used. These animals were fed a standard pellet diet and water ad libitum.

Chemicals. Cholic acid (CA), taurocholic acid (TCA), glycocholic acid (GCA), taurochenodeoxycholic acid (TCDCA) and glycochenodeoxycholic acid (GCDCA) were obtained from Sigma Chemical Co. (St. Louis, Mo., USA). According to the suppliers, these chemicals have a purity of $98 \%$. Chenodeoxycholic acid (CDCA), with a purity of $95 \%$ (TLC), was obtained from Calbiochem Co. Lipopolysaccharide JW (E. Coli 0127: B8) was obtained from Difco Labo. (Detroit, Michigan, USA).

Isolation and culture of Kupffer cells. Nonparenchymal liver cells were isolated by a procedure based on a method described by Knook and Sleyster (1976) and Munthe-Kaas et al. (1975). Under ether anesthetized the hamster livers were perfused in situ through the portal vein with Hanks' solution at $37^{\circ} \mathrm{C}$ for $2 \mathrm{~min}$ and $0.2 \%$ pronase $\mathrm{E}$ (Merck) in Hanks' solution at a rate of $5 \mathrm{ml} / \mathrm{min}$. The livers were then excised and minced. The paste-like liver substance was stirred in $86 \mathrm{ml}$ Hanks' solution with $0.2 \%$ pronase $\mathrm{E}$ using a magnetic stirrer at $37^{\circ} \mathrm{C}$ for $60 \mathrm{~min}$. The pellet was resuspended in $50 \%$ Percoll (Pharmacia Fine Chemicals, Uppsala, Sweden) and was centrifugated at $27,000 \mathrm{~g}$ for $30 \mathrm{~min}$. The cells in the middle layer were washed with Hanks' solution. The cell suspensions were diluted with Eagle's minimum essential medium (Nissui) plus 10\% FBS to a concentration of $2 \times 10^{6} \mathrm{cells} / \mathrm{ml}$. The nonparenchymal cells 

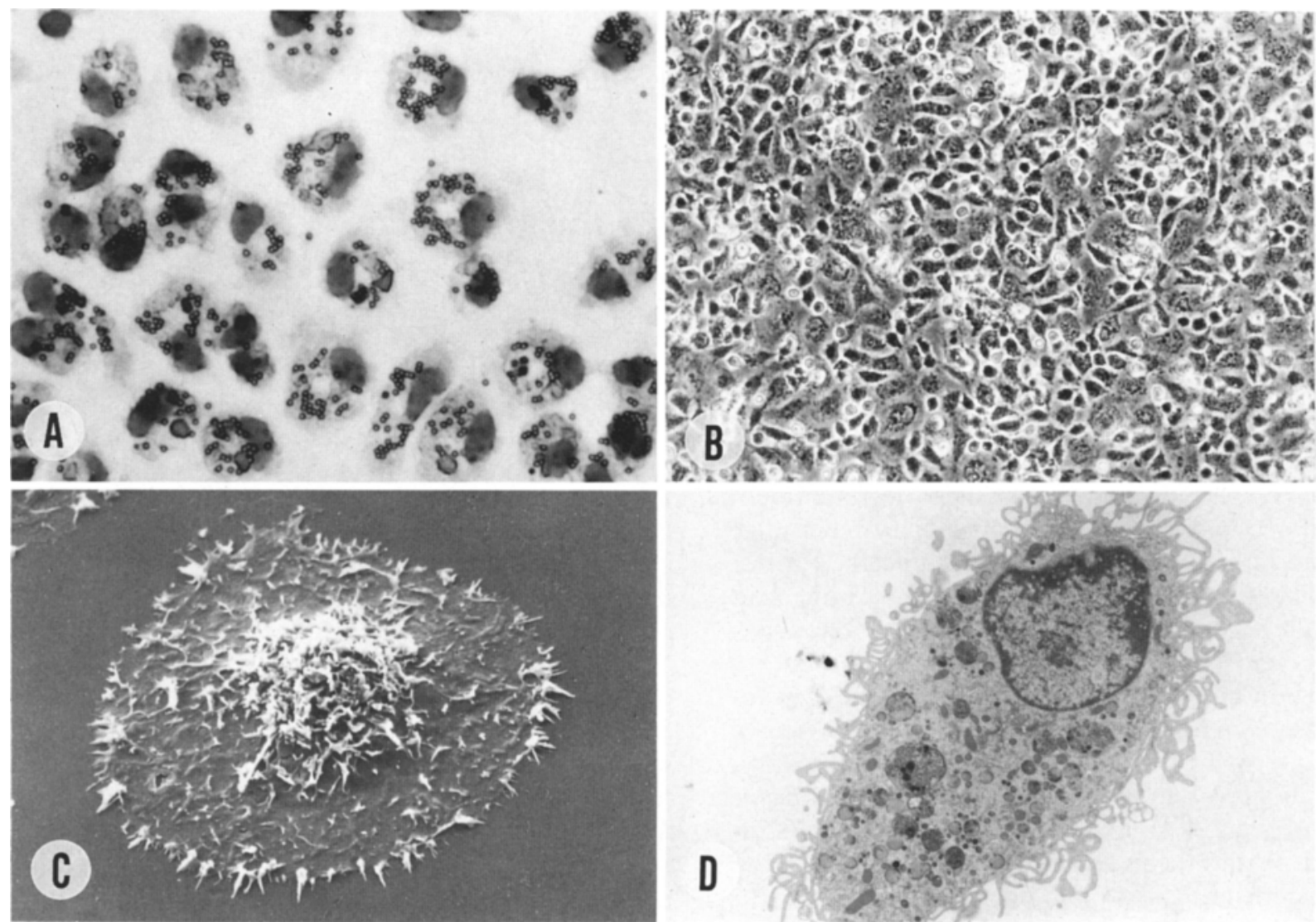

Fig. 1 A. Light micrograph showing KCs cultured for 2 days and incubated with latex particles $(1.091 \mu \mathrm{m}$ in diameter) for $1 \mathrm{~h}$. The cells which took up five or more particles are KCs. The purity was $91.2 \pm 3.4 \%$. Giemsa staining. $\times 1000$. (B) Phase contrast micrograph showing $\mathrm{KCs}$ cultured for 2 days. $2 \times 10^{6} \mathrm{NPC} / \mathrm{ml}$ were seeded. Adherent $\mathrm{KCs}$ are confluent. KCs are spindle-shaped or star-like and contain many dense bodies. $\times 250$. (C) Scanning electron micrograph showing one KC cultured for 2 days. Adherent KCs are $20-30 \mu \mathrm{m}$ in diameter and protrusion of the nucleus exists in the center of the cell, where microvilli are prominent. The extending cytoplasm forms ruffles. $\times 3000$. (D) Transmission electron micrograph showing a $\mathrm{KC}$ cultured for 2 days. The $\mathrm{KC}$ has many filopodia on the surface. Lysosomes, mitochondria, Golgi apparatus and endoplasmic reticulum are well developed. $\times 3500$

were cultivated in a plastic dish with a diameter of $35 \mathrm{~mm}$ (Falcon). After $24 \mathrm{~h}$ the medium was changed and after $48 \mathrm{~h}$ the cells were used for the experiments.

Treatment with bile acids and endotoxin. After $48 \mathrm{~h}$ culture, bile acids (CA, TCA, GCA, CDCA, TCDCA, or GCDCA) or endotoxin were incubated with the cells for $1,6,12$ and $24 \mathrm{~h}$. The final concentration of bile acids and endotoxin ranged from 0.5 to $5 \mathrm{mM}$ and from 2 to $100 \mu \mathrm{g} / \mathrm{ml}$, respectively. After incubation the medium was used for $\beta$-glucuronidase and lactate dehydrogenase assays.

The viability was $95.2 \%$ with $4 \mathrm{mM} \mathrm{CA}, 94.3 \%$ with $4 \mathrm{mM}$ TCA, $33.3 \%$ with $2 \mathrm{mM} \mathrm{CDCA}, 0 \%$ with $3 \mathrm{mM} \mathrm{CDCA}, 97.1 \%$ with $2 \mathrm{mM}$ TCDCA and $0 \%$ with $3 \mathrm{mM}$ TCDCA for $1 \mathrm{~h}$ incubation. It was 96.3 and $85.0 \%$ after incubation with endotoxin $100 \mu \mathrm{g} / \mathrm{ml}$ for $1 \mathrm{~h}$ and $24 \mathrm{~h}$, respectively.

Measurement of colloidal carbon pinocytosis and erythrophagocytosis. This procedure was based on the method of Kirn et al. (1980). After treatment with bile acids or endotoxin, the cells were washed with Hanks' solution and the medium was changed. After $1 \mathrm{~h}$, colloidal carbon (Pelikan Commercial Ink, Gunther Wagner, Hannover, FRG) was added to each dish $\left(400 \mu \mathrm{g} / 10^{5} \mathrm{Kupffer}\right.$ cells). After $1 \mathrm{~h}$ incubation at $37^{\circ} \mathrm{C}$, the cells were washed three times with PBS and then incubated with $1 \%$ sodium lauryl sulfate. The carbon content was determined by measuring the optical density (O.D.) at $750 \mathrm{~nm}$. Under these conditions, one unit of O.D. corresponded to $70 \mu \mathrm{g}$ colloidal carbon $/ \mathrm{ml}$. As Fc portions of rabbit Ig binds well to $\mathrm{Fc}$ receptors on hamster Kupffer cells, sheep erythrocytes opsonized with sheep erythrocyte antibodies produced in rabbits (Ishizu Pharmaceutical Co., Osaka, Japan) were added to each dish (final concentration, 40 erythrocytes/Kupfer cell) for $1 \mathrm{~h}$ at $37^{\circ} \mathrm{C}$. The cells were then treated with $0.85 \% \mathrm{NH}_{4} \mathrm{Cl}$ for $10 \mathrm{~min}$ to lyse the erythrocytes which were not internalized, washed three times with PBS and incubated with $1 \%$ sodium lauryl sulfate. The number of erythrocytes internalized was determined by measuring the hemoglobin content of the lysate at $410 \mathrm{~nm}$. Under these conditions, one unit of O.D. corrcsponded to $2.0 \times 10^{6} \mathrm{SRBC} / \mathrm{ml}$ of lysate.

Assay of $\beta$-glucuronidase and lactate dehydrogenase ( $L D H$ ) After treatment with bile acids or endotoxin, the medium was used for the assay of $\beta$-glucuronidase and LDH. $\beta$-glucuronidase was assayed spectrophotometrically with 4-nitrophenyl-Dglucuronid (Boehringer Mannheim GmbH, FRG) as the substrate, using the method of Kato et al. (1960). LDH was assayed a standard method (Babson and Philips 1965). 
Table 1. Endocytosis by cultured Kupffer cells treated with free bile acids for $1 \mathrm{~h}$

\begin{tabular}{llllll}
\hline $\begin{array}{l}\text { Concentration } \\
\text { of bile acids } \\
(\mathrm{mM})\end{array}$ & $\begin{array}{l}\text { C.C. pinocytosis } \\
\left(\mu \mathrm{g} / 10^{6} \mathrm{Kc}\right)\end{array}$ & $\begin{array}{l}\text { SRBC } \\
\text { phagocytosis } \\
\text { (SRBC/Kc) }\end{array}$ \\
\hline $\mathrm{CA}$ & 0 & $76.5 \pm 2.6$ & $(100)$ & $8.68 \pm 0.54$ & $(100)$ \\
& 0.5 & $75.1 \pm 6.3$ & $(98.1)$ & $7.14 \pm 0.34^{*}$ & $(82.3)$ \\
& 1.0 & $77.1 \pm 3.2$ & $(100.8)$ & $7.35 \pm 0.54^{*}$ & $(84.7)$ \\
& 2.0 & $60.1 \pm 10.2^{*}$ & $(78.5)$ & $5.88 \pm 0.41^{*}$ & $(67.7)$ \\
& 5.0 & $42.6 \pm 8.1^{*}$ & $(55.7)$ & $5.32 \pm 1.00^{*}$ & $(61.3)$ \\
CDCA & 0 & $69.0 \pm 8.9$ & $(100)$ & $9.24 \pm 0.91$ & $(100)$ \\
& 0.5 & $66.8 \pm 14.0$ & $(96.8)$ & $6.86 \pm 0.84^{*}$ & $(74.2)$ \\
& 1.0 & $43.0 \pm 16.8^{*}$ & $(62.4)$ & $5.46 \pm 0.50^{*}$ & $(59.1)$ \\
& 2.0 & $23.1 \pm 8.7^{*}$ & $(33.5)$ & $0.98 \pm 0.22^{*}$ & $(10.6)$ \\
& 5.0 & $1.4 \pm 0.8^{*}$ & $(2.1)$ & $0.98 \pm 0.32^{*}$ & $(10.6)$ \\
\hline
\end{tabular}

The data are expressed as mean $\pm S E$ of triplicates from four independent experiments

* $P<0.05$, compared with endocytosis without bile acids

Values in parentheses show the percentage of endocytosis without bile acids

C.C.: colloidal carbon, $S R B C$ : sheep red blood cell, $C A$ : cholic acid, $C D C A$ : chenodeoxycholic acid

\begin{abstract}
Morphology. Phase contrast micrography was performed with a Nikon KIAPHOT-TMD. The cells adherent to a cover slip (Lux) placed in the bottom of the dish at seeding were fixed with $2.5 \%$ glutaraldehyde in $0.1 \mathrm{M}$ cacodylate buffer for $1 \mathrm{~h}$, postfixed in $1 \% \mathrm{OsO}_{4}$ for $1 \mathrm{~h}$ and then dehydrated in a graded series of ethanol. The cover slips for scanning electron microscopy were immersed in isoamyl acetate and critical-point drying was carried out using Hitachi HCP-2. Fragments of dried samples were sputter-coated with gold. The samples were observed in, and photographed with, a "JEOL, JSM-840" electron microscope at $5 \mathrm{KV}$. The cover slips for transmission electron microscopy were embedded in Epon. Thin sections doubly stained with uranyl acetate and lead citrate were examined at $80 \mathrm{KV}$ in a JEOL JEM-100-CX electron microscope.
\end{abstract}

Statistical analysis. The values are expressed as mean $\pm \mathrm{SE}$. The unpaired Student's $t$-test was performed to determine the significance of differences between the means. $P$ values less than 0.05 were considered to be statistically significant.

\section{Results}

\section{Characterization of nonparenchymal cells (NPC)}

With this isolation method the yield of NPC was $7.2 \pm 2.6 \times 10^{7}$ cells/hamster. The viability after isolation was $95.4 \pm 3.8 \%$, determined by the trypan blue exclusion test. The purity by uptake of latex beads after 48 h culture was $91.2 \pm 3.4 \%$ (Fig. $1 \mathrm{~A}$ ). By phase contrast microscopy cultured Kupffer cells appeared spindle-shaped or star-like; they contained dense bodies and the nucleus was not sharply delineated (Fig. 1 B). By scanning electron microscopy adherent KCs were $20-30 \mu \mathrm{m}$ in diameter and the nucleus protruded in the center of the cell; microvilli were prominent and the extending cytoplasm formed ruffles (Fig. 1C). By trans- mission electron microscopy normally cultured $\mathrm{KCs}$ possessed numerous filopodia and contained well developed lysosomes, mitochondria, Golgi apparatuses and endoplasmic reticula (Fig. 1D).

\section{Effect of bile acids}

Free cholic acid at concentrations over $2 \mathrm{mM}$ and free chenodeoxycholic acid at concentrations over $1 \mathrm{mM}$ inhibited significantly colloidal carbon pinocytosis by KCs (Table 1). Free CA and free CDCA at concentrations over $0.5 \mathrm{mM}$ inhibited significantly IgG-coated SRBC phagocytosis by $\mathrm{KCs}$ (Table 1).

Since in vivo, bile acids which contact KCs are mostly conjugated, changes in endocytic functions of $\mathrm{KCs}$ were studied using conjugated bile acids. The endocytic function of KCs was progressively inhibited with increasing concentrations of bile acids.

There was no significant difference in SRBC phagocytosis between CA and TCA, except with 2 or $3 \mathrm{mM}$, between $\mathrm{CA}$ and GCA, between CDCA and GCDCA, except with $1 \mathrm{mM}$ and between CDCA and TCDCA (Table 2). There was no significant difference in colloidal carbon pinocytosis between $\mathrm{CA}$ and TCA, between $\mathrm{CA}$ and GCA, and between CDCA and TCDCA. There was a significant difference between $\mathrm{CDCA}$ and GCDCA (Table 3).

Table 4 shows the activity of $\beta$-glucuronidase released into the medium following treatment with bile acids. The activity increased significantly at concentrations of over $1 \mathrm{mM}$ CDCA, $2 \mathrm{mM}$ GCDCA, $2 \mathrm{mM}$ TCDCA, and $2 \mathrm{mM} \mathrm{CA}$. The increase occurring with CDCA was much greater than that with CA. LDH activity secreted into the medium from $\mathrm{KCs}$ after incubation with $4 \mathrm{mM}$ $\mathrm{CA}, 4 \mathrm{mM}$ TCA, $4 \mathrm{mM}$ CDCA and $4 \mathrm{mM}$ TCDCA was $0,3.7,7.4$ and $0 \mathrm{U}$, respectively. There were no significant differences from the control value $(17.4 \mathrm{U})$.

In phase contrast micrographs the KCs treated with $5 \mathrm{mM}$ CA became smaller rounded, and the cytoplasmic volume diminished (Fig. 2A). By scanning electron microscopy $\mathrm{KCs}$ were contracted and filopodia were revealed more clearly (Fig. 2B). $\mathrm{KCs}$ treated with $1 \mathrm{mM} \mathrm{CDCA}$ showed similar morphologic changes.

After treatment with CA or CDCA below concentrations of $5 \mathrm{mM}$ and $1 \mathrm{mM}$, respectively, the cells became rounded and the number of microvilli diminished as the concentration of bile acids increased. Mitochondria, endoplasmic reticulum and the nuclear envelope were vacuolized and lysosomes became scanty (Fig. 2C, D). 
Table 2. IgG-coated SRBC phagocytosis by cultured KCs treated with free and conjugated bile acids for $1 \mathrm{~h}$

\begin{tabular}{|c|c|c|c|c|c|}
\hline \multirow[t]{2}{*}{ Bile acids } & \multirow[t]{2}{*}{ Control } & \multicolumn{4}{|c|}{ Concentration of bile acids (mM) } \\
\hline & & 1 & 2 & 3 & 4 \\
\hline $\mathrm{CA}$ & $\begin{array}{l}3.89 \pm 0.89 \\
(100)\end{array}$ & $\begin{array}{l}2.84 \pm 0.51 \\
(73.0)\end{array}$ & $\begin{array}{l}2.38 \pm 0.32 \\
(61.3)\end{array}$ & $\begin{array}{l}1.79 \pm 0.23 \\
(45.9)\end{array}$ & $\begin{array}{l}1.54 \pm 0.81 \\
(39.6)\end{array}$ \\
\hline TCA & & $\begin{array}{l}3.85 \pm 0.63 \\
(99.1)\end{array}$ & $\begin{array}{l}3.57 \pm 0.40^{*} \\
(91.9)\end{array}$ & $\begin{array}{l}2.49 \pm 0.20^{*} \\
(64.0)\end{array}$ & $\begin{array}{l}2.00 \pm 0.24 \\
(51.4)\end{array}$ \\
\hline GCA & & & $\begin{array}{l}2.52 \pm 0.51 \\
(64.9)\end{array}$ & $\begin{array}{l}2.31 \pm 0.59 \\
(59.5)\end{array}$ & \\
\hline CDCA & $\begin{array}{l}4.52 \pm 0.27 \\
(100)\end{array}$ & $\begin{array}{l}0.88 \pm 0.63 \\
(19.4)\end{array}$ & $\begin{array}{l}0.42 \pm 0.31 \\
(9.3)\end{array}$ & $\begin{array}{l}0.39 \pm 0.23 \\
(8.5)\end{array}$ & $\begin{array}{l}0.42 \pm 0.20 \\
(9.3)\end{array}$ \\
\hline TCDCA & & $\begin{array}{l}2.07 \pm 0.14 \\
(45.7)\end{array}$ & $\begin{array}{l}0.21 \pm 0.12 \\
(4.7)\end{array}$ & $\begin{array}{l}0.21 \pm 0.12 \\
(4.7)\end{array}$ & $\begin{array}{l}0.04 \pm 0.02 \\
(0.8)\end{array}$ \\
\hline GCDCA & & $\begin{array}{l}2.52 \pm 0.28^{*} \\
(55.8)\end{array}$ & $\begin{array}{l}0.11 \pm 0.10 \\
(2.3)\end{array}$ & $\begin{array}{l}0.39 \pm 0.32 \\
(8.5)\end{array}$ & $\begin{array}{l}0.21 \pm 0.10 \\
(4.7)\end{array}$ \\
\hline
\end{tabular}

The data are expressed as mean $\pm \mathrm{SE}$ of triplicates from two independent experiments

Values show SRBC phagocytosis (SRBC/KC)

Values in parentheses show the percentage of control

* $P<0.05$, compared with phagocytosis of $\mathrm{KCs}$ treated with free bile acids

$C A$ : cholic acid, $T C A$ : taurocholic acid, $G C A$ : glycocholic acid, $C D C A$ : chenodeoxycholic acid, $T C D C A$ : taurochenodeoxycholic acid, $G C D C A$ : glycochenodeoxycholic acid

Table 3. Colloidal carbon pinocytosis by cultured $\mathrm{KCs}$ treated with free and conjugated bile acids for $1 \mathrm{~h}$

\begin{tabular}{|c|c|c|c|c|c|}
\hline \multirow[t]{2}{*}{ Bile acids } & \multirow[t]{2}{*}{ Control } & \multicolumn{4}{|c|}{ Concentration of bile acids (mM) } \\
\hline & & 1 & 2 & 3 & 4 \\
\hline $\mathrm{CA}$ & $\begin{array}{l}48.2 \pm 9.1 \\
(100)\end{array}$ & $\begin{array}{l}41.1 \pm 6.6 \\
(85.3)\end{array}$ & $\begin{array}{l}40.6 \pm 5.5 \\
(84.3)\end{array}$ & $\begin{array}{l}38.8 \pm 10.8 \\
(80.6)\end{array}$ & $\begin{array}{l}37.8 \pm 6.0 \\
(78.5)\end{array}$ \\
\hline TCA & & $\begin{array}{l}39.1 \pm 0.5 \\
(81.2)\end{array}$ & $\begin{array}{l}37.0 \pm 3.0 \\
(77.0)\end{array}$ & $\begin{array}{l}36.0 \pm 1.0 \\
(74.9)\end{array}$ & $\begin{array}{l}35.0 \pm 5.8 \\
(72.8)\end{array}$ \\
\hline $\mathrm{GCA}$ & & $\begin{array}{l}45.4 \pm 9.3 \\
(94.2)\end{array}$ & $\begin{array}{l}38.3 \pm 5.3 \\
(79.6)\end{array}$ & $\begin{array}{l}35.5 \pm 2.3 \\
(73.8)\end{array}$ & $\begin{array}{l}30.7 \pm 4.5 \\
(63.9)\end{array}$ \\
\hline $\mathrm{CDCA}$ & $\begin{array}{l}58.0 \pm 10.8 \\
(100)\end{array}$ & $\begin{array}{l}23.4 \pm 4.5 \\
(40.4)\end{array}$ & $\begin{array}{l}18.6 \pm 5.3 \\
(32.2)\end{array}$ & $\begin{array}{l}18.4 \pm 5.0 \\
(31.7)\end{array}$ & $\begin{array}{l}15.6 \pm 2.8 \\
(27.0)\end{array}$ \\
\hline TCDCA & & $\begin{array}{l}30.5 \pm 8.3 \\
(52.6)\end{array}$ & $\begin{array}{l}23.2 \pm 8.1 \\
(40.0)\end{array}$ & $\begin{array}{l}21.2 \pm 1.5 \\
(36.5)\end{array}$ & $\begin{array}{l}20.7 \pm 3.5 \\
(35.7)\end{array}$ \\
\hline GCDCA & & $\begin{array}{l}59.0 \pm 12.3 * \\
(101.7)\end{array}$ & $\begin{array}{l}46.6 \pm 4.3^{*} \\
(80.4)\end{array}$ & $\begin{array}{l}38.3 \pm 3.3^{*} \\
(66.1)\end{array}$ & $\begin{array}{l}35.3 \pm 11.6^{*} \\
(60.9)\end{array}$ \\
\hline
\end{tabular}

The data are expressed as mean $\pm \mathrm{SE}$ of triplicates from two independent experiments

Values show colloidal carbon pinocytosis $\left(\mu \mathrm{g} / 10^{6} \mathrm{KCs}\right)$

Values in parentheses show the percentage of control

* $P<0.05$, compared with pinocytosis of $\mathrm{KCs}$ treated with free bile acids

$C A$ : cholic acid, $T C A$ : taurocholic acid, $G C A$ : glycocholic acid, $C D C A$ : chenodeoxycholic acid, $T C D C A$ : taurochenoeoxycholic acid, $G C D C A$ : glycochenodeoxycholic acid

\section{Effect of endotoxin}

SRBC phagocytosis was inhibited significantly at concentrations over $100 \mu \mathrm{g} / \mathrm{ml}$ endotoxin after $1 \mathrm{~h}$ incubation and at concentrations over $50 \mu \mathrm{g} / \mathrm{ml}$ after 6, 12, and $24 \mathrm{~h}$ incubation (Fig. 3A).
Colloidal carbon pinocytosis was activated significantly by endotoxin at concentrations over $10 \mu \mathrm{g} / \mathrm{ml}$ after $1 \mathrm{~h}$ incubation, but was inhibited significantly at concentrations over $10 \mu \mathrm{g} / \mathrm{ml}$ after $24 \mathrm{~h}$ incubation. There was little change in pinocytosis after 6 and $12 \mathrm{~h}$ incubation (Fig. $3 \mathrm{~B}$ ). 
Table 4. $\beta$-glucuronidase in medium from cultured $\mathrm{KCs}$ treated with bile acids for $1 \mathrm{~h}$

\begin{tabular}{llllll}
\hline Bile acids & \multicolumn{5}{l}{ Concentration of bile acids $(\mathrm{mM})$} \\
\cline { 2 - 5 } & 0 & 1 & 2 & 3 & 4 \\
\hline CA & $25.5 \pm 4.5$ & $30.0 \pm 12.0$ & $43.5 \pm 5.2^{*}$ & $91.5 \pm 13.5^{*}$ & $120.0 \pm 19.5^{*}$ \\
& $(100)$ & $(118)$ & $(171)$ & $(359)$ & $(471)$ \\
CDCA & $19.2 \pm 1.2$ & $103.2 \pm 21.6^{*}$ & $148.8 \pm 8.4^{*}$ & $146.4 \pm 6.0^{*}$ & $132.0 \pm 3.6^{*}$ \\
& $(100)$ & $(538)$ & $(775)$ & $(762)$ & $(688)$ \\
TCDCA & $19.2 \pm 1.2$ & $18.0 \pm 2.4$ & $127.2 \pm 10.8^{*}$ & $122.4 \pm 8.4^{*}$ & $116.4 \pm 8.4^{*}$ \\
GCDCA & $(100)$ & $(94)$ & $(663)$ & $(638)$ & $(606)$ \\
& $19.2 \pm 1.2$ & $24.0 \pm 2.4$ & $153.6 \pm 9.6^{*}$ & $140.4 \pm 7.2^{*}$ & $141.6 \pm 20.4^{*}$ \\
\hline
\end{tabular}

Values show $\mathrm{U} / \mathrm{dl} \cdot \mathrm{h}$. The data are expressed as mean $\pm \mathrm{SE}$ of triplicates from two independent experiments Values in parentheses show the percentage of activity without bile acids

* $P<0.05$, compared with the activity without bile acids

$C A$ : cholic acid, $C D C A$ : chenodeoxycholic acid, $T C D C A$ : taurochenodeoxycholic acid, $G C D C A$ : glycochenodeoxycholic acid
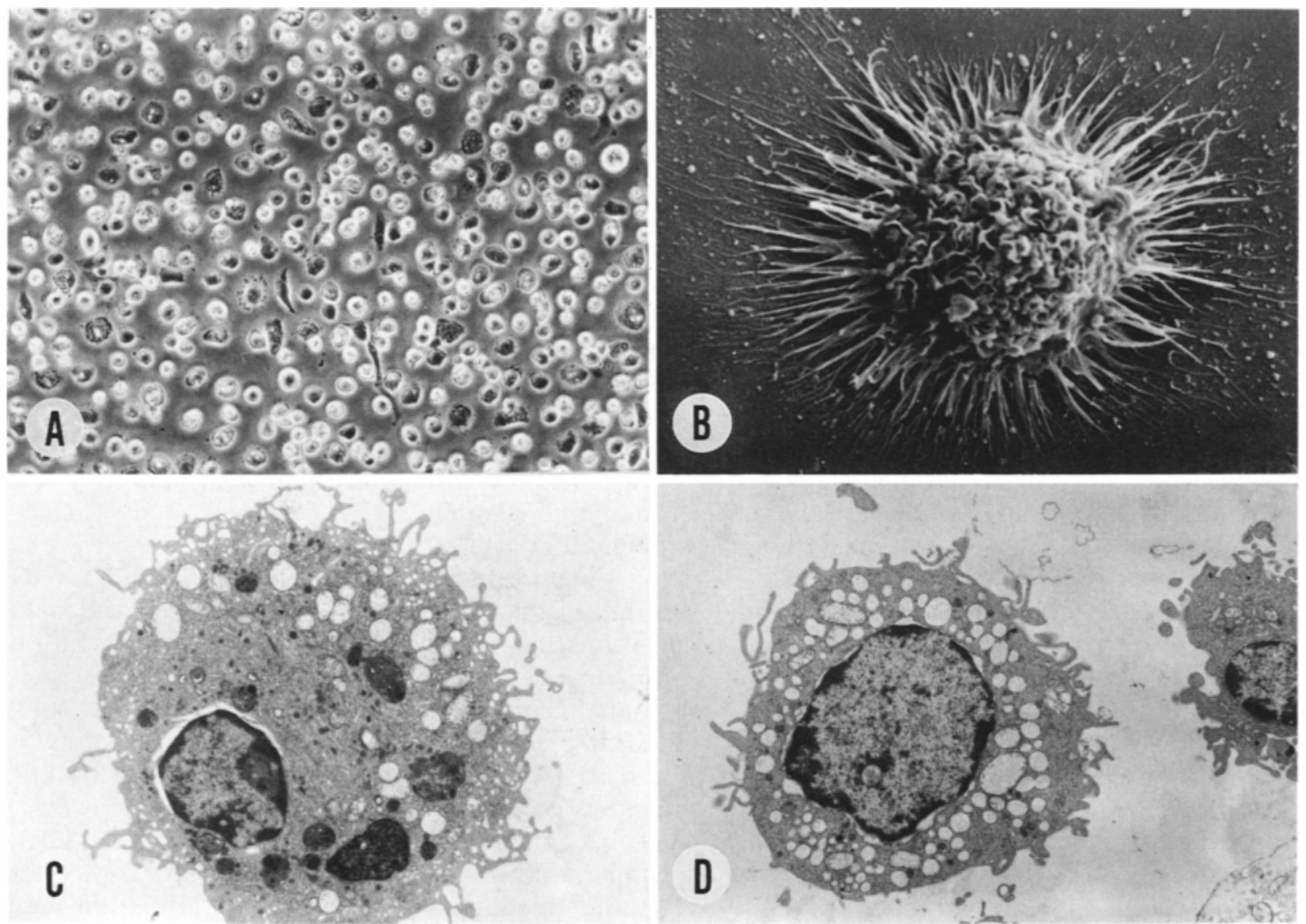

Fig. 2 A. Phase contrast micrograph showing KCs cultured for 2 days and treated with $5 \mathrm{mM}$ CA for $1 \mathrm{~h}$. The cytoplasm was reduced in volume and the $\mathrm{KCs}$ were round. Note the space between each $\mathrm{KC}$. $\times 500$. (B) Scanning electron micrograph showing KCs cultured for 2 days and treated with $5 \mathrm{mM} \mathrm{CA}$ for $1 \mathrm{~h}$. The KCs are contracted, the ruffles have disappeared and filopodia are clearly evident. $\times 5000$. (C) Transmission electron micrograph showing $\mathrm{KC}$ cultured for 2 days and treated with $5 \mathrm{mM} \mathrm{CA}$ for $1 \mathrm{~h} . \mathrm{KC}$ are rounded and the number of microvilli is reduced. Mitochondria, endoplasmic reticulum and the nuclear envelope are vacuolized and the lysosomes decreased in number. $\times 5000$. (D) Transmission electron micrograph showing $\mathrm{KC}$ cultured for 2 days and treated with $1 \mathrm{mM} \mathrm{CDCA}$ for $1 \mathrm{~h}$. The $\mathrm{KC}$ shows almost the same changes as those treated with $5 \mathrm{mM} C A$. $\times 8000$ 

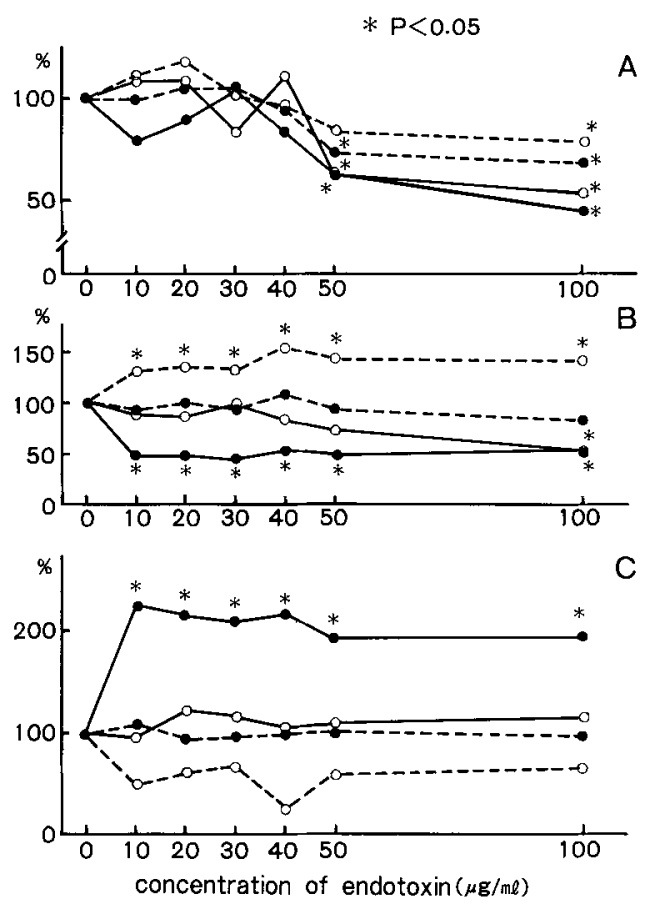

Fig. 3A. IgG-coated SRBC phagocytosis by cultured $\mathrm{KCs}$

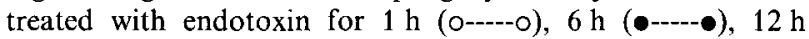
$(\mathrm{O}-\mathrm{O})$ and $24 \mathrm{~h}(\bullet-\bullet)$ is shown. The $P$ value is comparing KCs without endotoxin and phagocytosed $4.45 \pm 0.33$ SRBC/ $\mathrm{KC}$. B Colloidal carbon pinocytosis by cultured $\mathrm{KCs}$ treated with endotoxin for $1 \mathrm{~h}(\mathrm{O}----\mathrm{O}), 6 \mathrm{~h}(\bullet---\bullet), 12 \mathrm{~h}(\mathrm{o}-\mathrm{O})$ and $24 \mathrm{~h}(\bullet)$ is shown. The $P$ value is comparing $\mathrm{KCs}$ without endotoxin pinocytosed $40.7 \pm 5.1 \mu \mathrm{g} / 10^{6} \mathrm{KCs}$. C $\beta$-glucuronidase in medium from cultured $\mathrm{KCs}$ treated with endotoxin for $1 \mathrm{~h}(0----0), 6 \mathrm{~h}(\bullet---\bullet), 12 \mathrm{~h}(0-0)$ and $24 \mathrm{~h}$ $(\bullet)$ shown. The $P$ value represents a comparison with the activity without endotoxin

The activity of $\beta$-glucuronidase in the medium changed little after 1,6 and $12 \mathrm{~h}$ incubation with endotoxin at concentrations less than $100 \mu \mathrm{g} / \mathrm{ml}$ but increased significantly after $24 \mathrm{~h}$ incubation at concentrations over $10 \mu \mathrm{g} / \mathrm{ml}$ (Fig. 3C).

Colloidal carbon pinocytosis and $\beta$-glucuronidase secretion after incubation with lower concentrations of endotoxin showed the same tendency as with the higher concentrations (Table 5).

$\mathrm{LDH}$ activity secreted by $\mathrm{KCs}$ into the medium after incubation with 50 and $100 \mu \mathrm{g} / \mathrm{ml}$ endotoxin was 39.7 and $9.9 \mathrm{U}$, respectively. There were no significant differences from the control value (36.0 U).

$\mathrm{KCs}$ incubated with endotoxin became slightly enlarged and rounded, as viewed with phase contrast microscopy (Fig. 4A, B). By scanning electron microscopy the $\mathrm{KCs}$ were enlarged, the cell surface became granular, and the microvilli were reduced and appeared irregular (Fig. 4C). By transmission electron microscopy the $\mathrm{KCs}$ were seen to contain large vacuoles, suggesting the pres- ence of autophagic vacuoles in the cytoplasm. The plasma membrane, mitochondria, endoplasmic reticulum and Golgi apparatus changed little (Fig. 4D).

\section{Discussion}

Dysfunction of the hepatic reticuloendothelial system in clinical obstructive jaundice has been studied in vivo (Drivas et al. 1976; Holman and Rikkers 1982). As it is difficult to elucidate factors influencing Kupffer cells in vivo, cultured Kupffer cells were used in the present study. Rats are not a suitable species because chenodeoxycholic acid in jaundiced rats changes to $\beta$-muricholic acid and is detoxified (Greim et al. 1972; Danielsson 1973). Hamsters resemble humans with regard to biliary anatomy and the composition of bile acids (Anderson et al. 1972; Kuroki and Hoshita 1983), and were used in the present study.

This work revealed that primary bile acids (cholic acid and chenodeoxycholic acid) at concentrations over $0.5 \mathrm{mM}$ altered the cultured $\mathrm{KCs}$ both functionally and morphologically. The concentrations of bile acids used was higher than that in the serum in obstructive jaundice (Williams et al. 1975; Van Berge et al. 1976). However, the concentration of bile acids in bile canaliculi in obstructive jaundice has been measured to be $10-20 \mathrm{mM}$ (Klaasen 1971; Erlinger and Dhumeaux 1974). Bile acids in the bile duct enter the sinusoid through leaky tight junctions and capillaries and bile acids in hepatocytes may leak into the sinusoid (Forker 1969; Sternlieb and Quintana 1985). Therefore, the concentration of bile acids in sinusoids may rise to the concentrations used in this study (Scharschmidt et al. 1981).

Functional disturbances of cultured $\mathrm{KCs}$ by primary bile acids were assumed to be related to various mechanisms. One might be an alteration in the $\mathrm{Fc}$ receptor necessary to phagocyte IgGcoated SRBC (Munthe-Kaas 1976; Kaplan et al. 1975). The present study demonstrated that IgGcoated SRBC phagocytosis was inhibited by bile acids even at a concentration of $0.5 \mathrm{mM}$. However, at this concentration colloidal carbon pinocytosis, which does not require special receptors, was not inhibited, suggesting that receptor alteration may not be a major influence. The detergent effect of bile acids has been considered to be an important cause of cellular dysfunction (Fedorowski et al. 1978; Kakis and Yousef 1978). In our study, bile acids at concentrations over $0.5 \mathrm{mM}$ CDCA or $0.5 \mathrm{mM}$ CA interfered with the endocytic function of KCs. Although at these concentrations the 
Table 5. Colloidal carbon pinocytosis (A) and $\beta$-glucuronidase secretion (B) after incubation with lower endotoxin concentrations for $1 \mathrm{~h}$ and $24 \mathrm{~h}$

\begin{tabular}{|c|c|c|c|c|c|c|c|}
\hline & \multirow{2}{*}{$\begin{array}{l}\text { Incubation } \\
\text { time }\end{array}$} & \multicolumn{6}{|c|}{ Concentration of endotoxin $(\mu \mathrm{g} / \mathrm{ml})$} \\
\hline & & 0 (control) & 2 & 4 & 6 & 8 & 10 \\
\hline \multirow[t]{2}{*}{ A } & $1 \mathrm{~h}$ & $\begin{array}{c}67.5 \pm 11.5 \\
(100 \pm 17.2)\end{array}$ & $\begin{array}{c}117.5 \pm 11.5^{*} \\
(173.9 \pm 17.2)\end{array}$ & $\begin{array}{r}107.5 \pm 5.5^{*} \\
(158.6 \pm 7.9)\end{array}$ & $\begin{array}{c}124.0 \pm 13.0^{*} \\
(183.3 \pm 19.2)\end{array}$ & $\begin{array}{r}115.5 \pm 5.5^{*} \\
(170.9 \pm 7.9)\end{array}$ & $\begin{array}{c}126.0 \pm 14.0^{*} \\
(186.2 \pm 20.7)\end{array}$ \\
\hline & $24 \mathrm{~h}$ & $\begin{array}{c}48.5 \pm 6.5 \\
(100 \pm 13.8)\end{array}$ & $\begin{array}{c}32.5 \pm 4.0 \\
(67.6 \pm 8.3)\end{array}$ & $\begin{array}{c}29.5 \pm 6.5 \\
(61.4 \pm 13.8)\end{array}$ & $\begin{array}{c}25.5 \pm 2.5^{*} \\
(52.4 \pm 4.8)\end{array}$ & $\begin{array}{c}29.0 \pm 4.0^{*} \\
(60.0 \pm 8.3)\end{array}$ & $\begin{array}{r}28.5 \pm 3.0^{*} \\
(58.6 \pm 6.2)\end{array}$ \\
\hline \multirow[t]{2}{*}{$\mathrm{B}$} & $1 \mathrm{~h}$ & $\begin{array}{c}186.0 \pm 12.0 \\
(100 \pm 6.5)\end{array}$ & $\begin{array}{c}200.0 \pm 1.6 \\
(107.5 \pm 1.1)\end{array}$ & $\begin{array}{l}166.0 \pm 10.2 \\
(89.2 \pm 5.4)\end{array}$ & $\begin{array}{c}200.6 \pm 4.4 \\
(107.5 \pm 2.2)\end{array}$ & $\begin{array}{l}180.1 \pm 14.2 \\
(96.8 \pm 7.5)\end{array}$ & $\begin{array}{c}186.3 \pm 12.4 \\
(100 \pm 6.5)\end{array}$ \\
\hline & $24 \mathrm{~h}$ & $\begin{array}{c}194.1 \pm 16.2 \\
(100 \pm 8.2)\end{array}$ & $\begin{array}{c}218.3 \pm 10.4 \\
(112.3 \pm 5.2)\end{array}$ & $\begin{array}{c}252.3 \pm 16.2^{*} \\
(129.9 \pm 8.2)\end{array}$ & $\begin{array}{c}252.4 \pm 10.4^{*} \\
(129.9 \pm 5.2)\end{array}$ & $\begin{array}{c}250.0 \pm 14.4^{*} \\
(128.9 \pm 7.2)\end{array}$ & $\begin{array}{r}254.4 \pm 18.2^{*} \\
(130.9 \pm 9.3)\end{array}$ \\
\hline
\end{tabular}

The data are expressed as (A) $\mu \mathrm{g} / 10^{6} \mathrm{KCs}$ and (B) $\mathrm{U} / \mathrm{dl} \cdot \mathrm{h}$

The data are expressed as mean $\pm \mathrm{SE}$ of triplicates from one experiments

* $P<0.05$, compared with control

Values in parentheses show the percentage of control
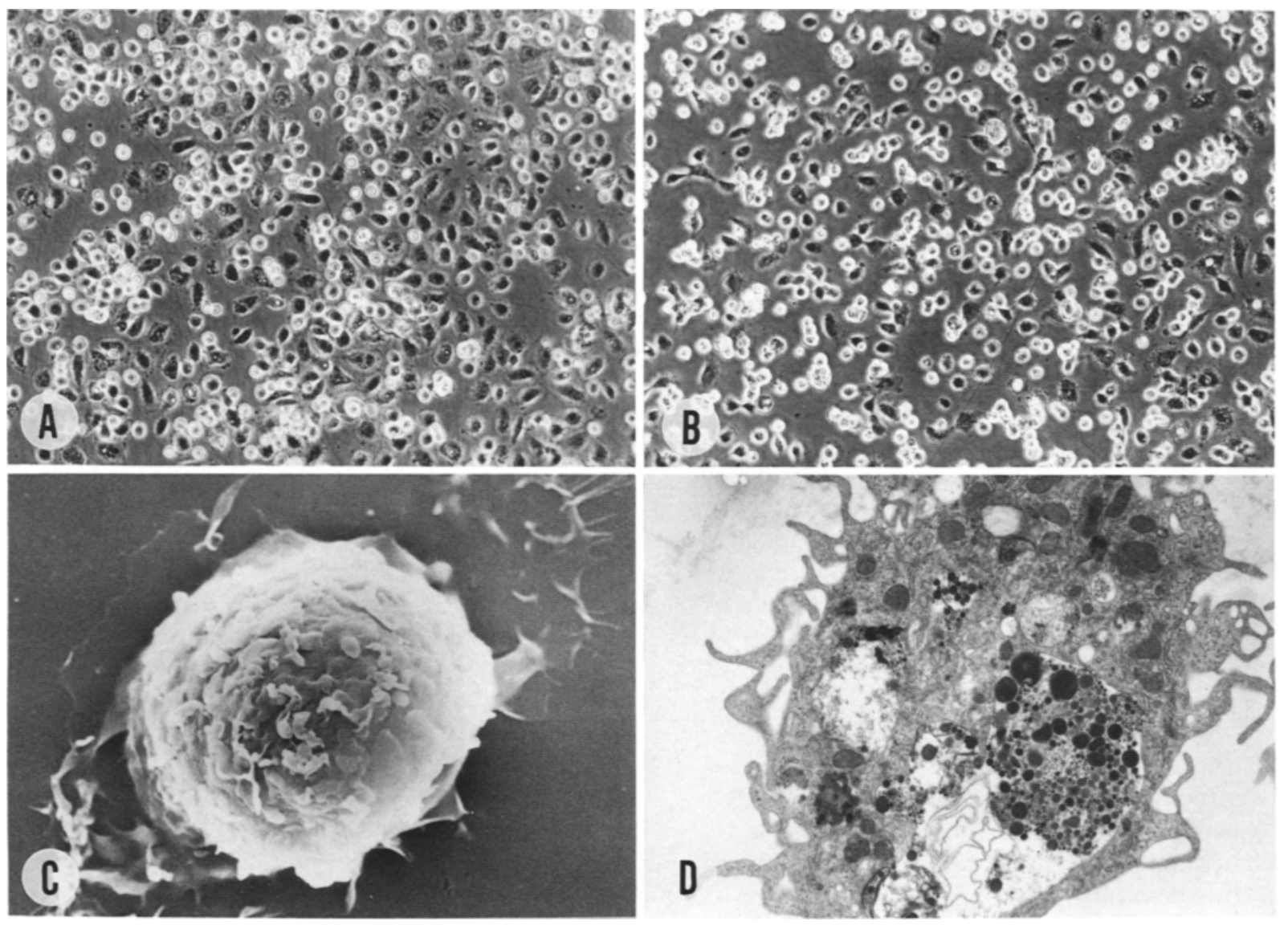

Fig. 4A. Phase contrast micrograph showing $\mathrm{KCs}$ cultured for 2 days and treated with endotoxin $100 \mu \mathrm{g} / \mathrm{ml}$ for $1 \mathrm{~h}$. The $\mathrm{KCs}$ are slightly enlarged and rounded. $\times 250$. (B) Phase contrast micrograph showing KCs cultured for 2 days and treated with endotoxin $100 \mu \mathrm{g} / \mathrm{ml}$ for $24 \mathrm{~h}$. There are no conspicious changes, compared with the findings after $1 \mathrm{~h}$ incubation. $\times 500$. (C) Scanning electron micrograph showing $\mathrm{KC}$ cultured for 2 days and treated with endotoxin $100 \mu \mathrm{g} / \mathrm{ml}$ for $24 \mathrm{~h}$. The $\mathrm{KC}$ is enlarged, the cell surface is granular, the microvilli are reduced in number and appear irregular. (D) Transmission electron micrograph showing KC cultured for 2 days and treated with endotoxin $100 \mu \mathrm{g} / \mathrm{ml}$ for $24 \mathrm{~h}$. The $\mathrm{KC}$ is expanded with large vacuoles originated from lysosomes. Cytoplasmic membrane, mitochondria, endoplasmic reticulum and nuclear envelope are intact. $\times 8000$ 
membrane of KCs did not seem to be altered, the cellular organelles showed definite changes. Therefore, plasma membrane damage may not be the primary event. The pseudopodia and microvilli decreased in number and were shortened with increased concentrations of bile acids, hence, the microfilaments may also play a important role in $\mathrm{KC}$ function. In our study, the lysosomes decreased in number and $\beta$-glucuronidase activity in the medium increased as the concentration of bile acids increased. Dysfunction may follow the decrease in lysosomal fusion degradation, which is the last step of endocytosis after attachment to the cell membrane, internalization and intracellular transport (Praaning-van Dalen et al. 1982), secondary to damage and decrease of lysosomes.

In our experiments, endocytic function and $\beta$ glucuronidase release by $\mathrm{KCs}$ were activated after incubation with endotoxin for $1 \mathrm{~h}$, but were inhibited after incubation for $24 \mathrm{~h}$. Tanner et al. (1983) reported that $\mathrm{N}$-acetyl- $\beta$-glucosaminidase (NAG) produced by resident macrophages was unchanged following endotoxin exposure for $2 \mathrm{~h}$ but increased when stilboestrol and Corynebacterium parvum were given to the donor rats before the macrophages were isolated. Bhatnagar et al. (1981) reported that chemiluminescence and $\mathrm{O}_{2}^{-}$production by cultured rat $\mathrm{KCs}$ were activated by incubation with zymosan for less than 40 min. Their data parallel ours with regard to incubation with endotoxin for $1 \mathrm{~h}$. However, we did not demonstrated that cultured $\mathrm{KCs}$ are activated by endotoxin, because the species used, incubation time, activator and parameters differed.

At endotoxin concentrations over $50 \mu \mathrm{g} / \mathrm{ml}$, SRBC phagocytosis by KCs was inhibited; but colloidal carbon pinocytosis was not inhibited with similar concentrations of endotoxin and incubation for less than $12 \mathrm{~h}$. It was reported that the concentration of endotoxin in vivo did not exceed $50 \mu \mathrm{g} / \mathrm{ml}$ (Al-Tuwaijri et al. 1981; Kuratsune et al. 1983). Therefore, the concentration of endotoxin which inhibited the endocytic function of KCs in this study was much higher than the concentration measured in vivo. The mechanism by which endotoxin caused damage to cultured $\mathrm{KCs}$ differed from that caused by primary bile acids. The $\mathrm{KCs}$ exposed to endotoxin had many cytoplasmic vacuoles considered to have originated from lysosomes and cell swelling in vivo (Frenzel et al. 1977; McCuskey et al. 1983) and in vitro (Maier and Ulevitch 1981; Morland and Kaplan 1977). The present study confirmed that the same changes occurred with $100 \mu \mathrm{g} / \mathrm{ml}$ endotoxin. Therefore, $\mathrm{KC}$ dysfunction after the application of endotoxin was considered to be caused by excessive endocytosis (Mathison and Ulevitch 1979; Ruiter et al. 1981).

In our study, $\mathrm{KCs}$ treated with bile acids for $1 \mathrm{~h}$ at concentrations over $2 \mathrm{mM}$ CA or $1 \mathrm{mM}$ CDCA produced significant increases in the concentration of $\beta$-glucuronidase in the culture medium. KCs treated with bile acids for $24 \mathrm{~h}$ produced similar changes (data not shown). It was therefore assumed that $\beta$-glucuronidase secretion by $\mathrm{KCs}$ treated with bile acids was dose-dependent. When endotoxin carried to the liver is taken up and detoxified by KCs (Mathison and Ulevitch 1979; Praaning-Van Dalen et al. 1981), $\beta$-glucuronidase is secreted by these cells. In our study, the secretion of $\beta$-glucuronidase did not increase with $100 \mu \mathrm{g} / \mathrm{ml}$ of endotoxin after less than $12 \mathrm{~h}$ incubation, but did increase with $10 \mu \mathrm{g} / \mathrm{ml}$ endotoxin after $24 \mathrm{~h}$ incubation. Therefore, the activation of KCs seemed to depend on the incubation time. There was also a difference between bile acids and endotoxin with regard to their effects on the secretion of $\beta$-glucuronidase from KCs.

We tentatively conclude that primary bile acids rather than endotoxin influence $\mathrm{KC}$ function in obstructive jaundice.

The present study demonstrated that primary bile acids and endotoxin altered the function and morphology of the KCs in vitro. However, in vivo, other factors have to be considered and the interaction of these factors requires attention. It was reported that the absorption of endotoxin from the intestine increased as the bile acids in intestine decreased and that the reverse was also true (Bailey 1976; Cahill 1983). It was also reported that bile acid itself has a detergent effect on endotoxin (Shands and Chun 1980; Evans et al. 1982).

Acknowledgement. We thank Prof. F. Nakayama, Department of Surgery I, Faculty of Medicine, Kyushu University for valuable advice during this work.

\section{References}

Adler RD, Wannagat FJ, Ockner RK (1977) Bile secretion in selective biliary obstruction. Gastroenterology 73:129-136

Al-Tuwaijri A, Akdamar K, Di Luzio NR (1981) Modification of galactosamine-induced liver injury in rats by reticuloendothelial system stimulation or depression. Hepatology $1: 107-113$

Anderson KE, Kok E, Javitt N (1972) Bile acid synthesis in man; metabolism of 7-hydroxycholesterol $\mathrm{C}$ and 26-hydroxycholesterol- H. J Clin Invest $51: 112-117$

Babson AL, Philips GE (1965) A rapid colorimetric assay for serum lactic dehydrogenase. Clin Chim Acta 12:210-215

Bailey ME (1976) Endotoxin, bile salts and renal function in obstructive jaundice. Br J Surg 63:774-778

Bhatnagar R, Schirmer R, Ernst M, Decker K (1981) Superox- 
ide release by zymosan-stimulated rat Kupffer cells in vitro. Eur J Biochem 119:171-175

Cahill CJ (1983) Prevention of postoperative renal failure in patients with obstructive jaundice - the role of bile salts. Br J Surg 70:590-595

Danielsson $H$ (1973) Effect of biliary obstruction on formation and metabolism of bile acids in rat. Steroid 22:567-579

Drivas G, James O, Warkle N (1976) Study of reticuloendothelial phagocytic capacity in patients with cholestasis. Br Med J $1: 1568-1569$

Eklund A, Norlander A, Norman A (1980) Bile acid synthesis and excretion following release of total extrahepatic cholestasis by percutaneous transhepatic drainage. Eur J Clin Invest $10: 349-355$

Erlinger S, Dhumeaux D (1974) Mechanism and control of secretion of bile, water and electrolytes. Gastroenterology 66:281-304

Evans HJR, Torrealbe V, Hudd C, Knight M (1982) The effect of preoperative bile salt administration on postoperative renal function in patients with obstructive jaundice. Br J Surg 69:706-708

Fedorowski T, Salen G, Zaki FG, Shefer S, Mosbach EH (1978) Comparative effects of ursodeoxycholic acid and chenodeoxycholic acid in the rhesus monkey. Gastroenterology $74: 75-81$

Forker EL (1969) The effect of estrogen on bile formation in the rat. J Clin Invest 48:654-663

Frenzel H, Kremer B, Hucker H (1977) In: Wisse E, Knook DL (eds) Kupffer cells and other liver sinusoidal cells. Elsevier/North-Holland, Amsterdam, pp 213-222

Greim H, Trulzsch D, Roboz J, Dressler K, Crygan P, Hutterer F, Schaffner F, Popper H (1972) Mechanism of cholestasis 5. Bile acids in normal rat livers and in those after bile duct ligation. Gastroenterology 63:837-845

Holman JM Jr, Rikkers LF (1982) Biliary obstruction and host defense failure. J Surg Res 32:208-213

Kakis G, Yousef IM (1978) Pathogenesis of lithocholate and taurolithocholate-induced intrahepatic cholestasis in rats. Gastroenterology 75:595-607

Kaplan G, Gandernack G, Seljelid R (1975) Localization of receptors and early events of phagocytosis in the macrophage. Exp Cell Res 95:365-375

Kato K, Yoshida K, Tsukamoto H, Nobunaka M, Masuya T, Sawada T (1960) $\beta$-D-glucophranosiduronic acid and its utilization as a substrate for the assay of $\beta$-glucuronidase activity. Chem Pharmaceut Bull 8:239-242

Keller GA, West MA, Cerra FB, Simmons RJ (1985) Multiple systems organ failure. Modulation of hepatocyte protein synthesis by endotoxin activated Kupffer cells. Ann Surg 201:87-95

Kirn A, Steffan AM, Bingen A (1980) Inhibition of erythrophagocytosis by cultured rat Kupffer cells infected with Frog Virus 3. J Reticuloendothel Soc 28:381-389

Klaassen CD (1971) Does bile acid secretion determine canalicular bile production in rats? Am J Physiol 220:667-673

Knook DL, Sleyster ECH (1976) Separation of Kupffer and endothelial cells of the rat liver by centrifugal elutriation. Exp Cell Res 99:444 449

Kuratsune H, Koda T, Kurahori T (1983) The relationship between endotoxin and the phagocytic activity of the reticuloendothelial system. Hepato Gastroenterol 30:79-82

Kuroki S, Hoshita T (1983) Effect of bile acid feeding on he- patic steroid $12 \alpha-$ Hydroxylase activity in hamsters. Lipids 18:789-794

Maier RV, Ulevitch RJ (1981) The response of isolated rabbit hepatic macrophages. Circ Shock 8:165-181

Mathison JC, Ulevitch RJ (1979) The clearance, tissue distribution and cellular localization of intravenously injected lipopolysaccharide in rabbits. J Immunol $123: 2133-2143$

McCuskey RS, Urbascek R, McCuskey PA, Urbascek B (1983) In vivo microscopic observations of the responses of Kupffer cells and the Mycobacterium bovis BCG alone and in combination with endotoxin. Infect Immun 42:362-367

Morland B, Kaplan G (1977) Macrophage activation in vivo and in vitro. Exp Cell Res 108:279-288

Munthe-Kaas AC (1976) Phagocytosis in rat Kupffer cells in vitro. Exp Cell Res 99:319-327

Munthe-Kaas AC, Berg T, Seglen PO, Seljelid R (1975) Mass isolation and culture of rat Kupffer cells. J Exp Med $141: 1-10$

Oka K, Shimamura K, Nakazawa M, Tsunoda R, Kojima M (1983) The role of Kupffer cells in disseminated intravascular coagulation. Arch Pathol Lab Med 107:570-576

Praaning-van Dalen DP, Brouwer A, Knook DL (1981) Clearance capacity of rat liver Kupffer, endothelial, and parenchymal cells. Gastroenterology 81 :1036-1044

Praaning-van Dalen DP, De Leeuw AM, Brouwer A, Knook DL (1982) In: Knook DL, Wisse E (eds) Sinusoidal Liver Cells. Elsevier/North-Holland, Amsterdam, pp 517-524

Ruiter DJ, Meulen J, Brouwer A, Hummel MJR, Mauw BJ, Ploeg JCM, Wisse E (1981) Uptake by liver cells of endotoxin following its intravenous injection. Lab Invest $45: 38-45$

Scharschmidt BF, Keefee EB, Bessey DA, Blankenship NM, Ockner RK (1981) In vitro effect of bile salts on rat liver plasma membrane, lipid fluidity, and ATPase activity. Hepatology $1: 137-145$

Shands JW jun, Chun PW (1980) The dispersion of Gram negative lipopolysaccharide by deoxycholate. J Biol Chem 255:1221-1226

Sternlieb I, Quintana N (1985) Biliary proteins and ductular ultrastructure. Hepatology 5:139-143

Tanner AR, Keyhani AH, Ralph W (1983) The influence of endotoxin in vitro on hepatic macrophage lysosomal enzyme release in different rat models of hepatic injury. Liver $3: 151-160$

Van Berge Hene Gouwen GP, Brandt KH, Eyssen H, Parmentier $G$ (1976) Sulphated and unsulphated bile acids in serum, bile, and urine of patients with cholestasis. Gut 17:861-869

Wardle EM, Wright NA (1970) Endotoxin and acute renal failure associated with obstructive jaundice. $\mathrm{Br}$ Med J $21: 472-474$

Wilkinson SP, Arroyo V, Gazzard BG, Moodie H, Williams $R$ (1974) Relation of renal impairment and hemorrhagic diathesis the endotoxemia in fulminant hepatic failure. Lancet $1: 521-524$

Wilkinson SP, Moodie H, Stamatakis JD, Kakkar VV, Williams R (1976) Endotoxemia and renal failure in cirrhosis and obstructive jaundice. Br Med J 2:1415-1418

Williams RC, Showalter R, Kern F (1975) In vivo effect of bile salts and cholestyramine on intestinal anaerobic bacteria. Gastroenterology 69:483 491

Received February 25 / Accepted October 22, 1987 